\title{
Lessons from Indonesia's 1980 trawler ban
}

\author{
Conner Bailey
}

In 1980 the Indonesian government imposed a ban on trawling along the Malacca Straits and off the north coast of Java, the nation's two most important fishing grounds. The ban on trawling was extended nation-wide in 1981, effectively eliminating a highly productive type of fishing gear and the most important source of shrimp for the lucrative international market. The political nature of this decision and factors contributing to what has proven to be effective enforcement are discussed. Data on the Malacca Straits and the north coast of Java are used to assess the consequences of the trawler ban on the demersal fisherles. Prior to the trawler ban, little or no growth occurred in numbers of fishers, numbers of smallscale demersal gear, or landings by small-scale demersal gear. After 1980, however, small-scale demersal fisheries experienced dramatic growth, generating signiflcant new employment opportunities but raising anew serious resource management problems. (C) 1997 Elsevier Science Ltd

Key words - Indonesia, fisheries management, trawlers

Conner Bailey is at the Department of Agricultural Economics and Rural Sociology, Auburn University, Auburn, AL 36849-5406, USA, email: cbailey@acesag.auburn.edu.

\section{Introduction}

Over the past 30 years, coastal fisheries in Southeast Asia have been a battleground where large numbers of small-scale fishers have been pitted against a comparative handful of trawler operators. Under the open-access conditions that have prevailed in most Southeast Asian fisheries, the expansion of trawler operations has been a primary cause of overfishing and resource depletion [1]. The problem has been particularly serious because trawler operators and small-scale fishers generally exploit the same resource and often compete for access to the same coastal fishing grounds. Trawlers are attracted to these waters by the presence of penaeid shrimp, which are most densely concentrated in coastal waters [2]. The resulting competition between trawler operators and small-scale fisheries has led to widespread conflict in Indonesia and elsewhere in Southeast Asia [3-6].

Indonesia is the only country in the region to have addressed this issue of competition and conflict effectively. In 1980, Presidential Decree No. 39 imposed a ban on the use of trawlers in waters off Java and Sumatra as of October of that year, essentially reallocating resources in favor of small-scale fishers. In 1981, Presidential Letter of Instruction No. 11 extended the ban nationwide (with the exception of the Arafura Sea, where large foreign operated joint-venture trawlers had not elicited a violent local response). The ban was particularly remarkable because trawlers at that time were the nation's most important fishing gear as measured both by total landings and by contributions to foreign exchange earnings. Moreover, this action was taken at the expense of relatively wealthy and politically well-connected trawler owners. The trawler ban attracted considerable attention at the time, [7-9] but no attention has been given to the long-term consequences of this action.

The purpose here is to assess the impact of the 1980 trawler ban on demersal resources and landings, shrimp exports, and employment in the two areas of Indonesia affected by this policy, the Malacca Straits and the north coast of Java. Between 1975 and 1980, trawlers in these two areas accounted for more than half of all trawlers in Indonesia as well as more than half of total trawler landings [10]. The Malacca 
Straits and the north coast of Java are Indonesia's most important fishing grounds. In 1980, the year trawlers were banned, these two areas combined accounted for $44 \%$ of landings by all gear in Indonesia, 33\% of the national fishing fleet, and $39 \%$ of all Indonesians employed in fishing [11].

The analysis is based on both primary and secondary data. Annual reports covering the period 1975-1993 (the most recent data available) prepared by Indonesia's Directorate General of Fisheries will be used to trace changes in landings and employment. The quality of DGF data published since 1975 are sufficiently reliable for the analysis of trends [12]. Other published secondary data will be used to examine changes affecting resource availability and shrimp exports. Primary data in the form of field observations and interviews provide the context for interpreting these secondary data. The author lived in and traveled throughout Indonesia during 1981-1982, immediately after the ban was promulgated, and made a series of short-term visits to Indonesia in 1984 and during the period 1989-1992.

\section{Origins and growth of Indonesia's trawling fleet}

Trawling was first adopted in Indonesia during 1966 by ethnic Chinese fishers operating from the town of Bagan Siapi-api on the Malacca Straits. These fishers learned the technique of trawling from Malaysian fishers (also ethnically Chinese) from the other side of the Straits, who in turn had learned how to trawl from Thai fishers [4]. During the 1970s trawling spread rapidly from Bagan Siapi-api to other areas along the Malacca Straits, the north coast of Java, and other areas of the country [13, 14] . Both the Malacca Straits and the north coast of Java can be characterized as relatively shallow with sandy or muddy bottoms well suited to trawling.

The typical Indonesian trawler was a wooden hulled boat displacing 30 gross tons and powered by an inboard diesel engine generating 100 200 h.p. Total investment costs for what became known locally as a "Bagan Siapi-api trawler" were approximately US\$20000 in 1978 [15]. Such trawlers were relatively small by international standards, but in Indonesia they represented a quantum leap in fishing power compared to the technologies available to small-scale fishers. In 1980 , over $80 \%$ of Indonesia's fishing fleet was non-motorized [11]. Bagan Siapi-api trawlers had a crew of five and were rigged to pull an otter trawl with cod-end mesh of $20-25 \mathrm{~mm}$. Shrimp were the primary target species. Initially, those who invested in trawlers were from the fishing industry itself, but the profitability of trawling was such that investors from other sectors of the economy were attracted into the fishery. Both in Malaysia and Indonesia, these initial investors were of Chinese descent. The presence of social and economic ties linking Chinese communities on both sides of the Malacca Straits probably was a factor contributing to the rapid adoption and diffusion of trawlers in Indonesia. In Malaysia, early adopters were able to recoup their capital investment costs in as little as six months [16]. No comparable figures are available for Indonesia, but the rapid adoption of trawlers during the late 1960s and early 1970 s clearly indicates the attraction of this investment. Indonesians of Chinese descent were not the only investors in trawlers, however. By 1980 , the ranks of trawler owners included retired military officers and local entrepreneurs from urban port cities. 
Sources: Directorate General of Fisheries, Fisheries Statistics of Indonesia, various years.
Table 1. Number of Indonesian otter trawlers and annual catch rates (mt), 1975-1981

\begin{tabular}{llccccc}
\hline Year & No. & $\begin{array}{c}\text { Indonesia } \\
\text { Catch rate }\end{array}$ & No. & Malacca Straits & \multicolumn{2}{c}{ North Coast Java } \\
Catch rate
\end{tabular}

Five years after their introduction, 800 Indonesian trawlers were operating in the Malacca Straits alone [14]. This led to increased pressure on demersal resources so that by the early 1970 s catch rates of trawlers in this area were declining [17]. By 1971, at least 50 trawlers had shifted operations from the Malacca Straits to the north coast of Java, and trawling had been introduced to the area of Cilacap, the one part of the south coast of Java that had extensive trawlable grounds [14]. The first year for which comprehensive data are available on numbers of trawlers in Indonesia is 1975. In that year there were 2305 otter trawlers operating in Indonesian waters (Table 1), nine years after they were first introduced. The most rapid period of growth occurred between 1975 and 1977, when the number of trawlers increased by $70 \%$.

\section{Resource competition and conflict}

Data on Indonesia's demersal fisheries resources clearly indicate that, during the period 1975-1979, both the Malacca Straits and the north coast of Java were being overfished [10]. Trawlers were not the only source of fishing pressure on demersal resources as large numbers of small-scale fishers using a wide range of fishing gear also exploited demersal stocks. In the Malacca Straits, during the late 1970s there were on average over 15000 small-scale demersal gear units competing with trawlers for the same stock (Table 2). Despite their relatively small numbers (approximately $7 \%$ of all demersal gear in the Malacca Straits), trawlers accounted for $39 \%$ of total demersal catch during the

\begin{tabular}{llll}
\hline \multicolumn{1}{l}{ Table 2. Small-scale demersal gear in the Malacca Straits, $\mathbf{1 9 7 5 - 1 9 9 3}$} & \\
\hline Year & Number & Tolal landings (mt) & Catch rates (mt) \\
1975 & 12694 & 115301 & 9.08 \\
1976 & 16141 & 69143 & 4.28 \\
1977 & 14019 & 77492 & 5.53 \\
1978 & 14469 & 77293 & 5.34 \\
1979 & 16540 & 92999 & 5.62 \\
1980 & 16792 & 103028 & 6.14 \\
1981 & 22937 & 112498 & 4.90 \\
1982 & 23040 & 105994 & 4.60 \\
1983 & 19003 & 133530 & 7.03 \\
1984 & 21376 & 153239 & 7.17 \\
1985 & 22394 & 153058 & 6.83 \\
1986 & 26771 & 174037 & 6.50 \\
1987 & 27091 & 193594 & 7.15 \\
1988 & 28328 & 208263 & 7.35 \\
1989 & 33811 & 219286 & 6.49 \\
1990 & 34103 & 183366 & 5.38 \\
1991 & 31720 & 213223 & 6.72 \\
1992 & 33316 & 220801 & 6.63 \\
1993 & 32457 & 230816 & 7.11 \\
$\%$ change $1980-93$ & 93.3 & 124.0 & 15.8 \\
\hline
\end{tabular}

Sources: Directorate General of Fisheries, Fisheries Statistics of Indonesia, various years. Note: Numbers of fishers and boats are totals for the Malacca Straits. Demersal gear included in this table are Danish seine, Beach seine, shrimp gill nets, bottom-set gill nets trammel nets, bottom-set long lines, hook and lines, guilding barriers, stow nets, portable traps, and other traps. Descriptions of these gear can be found in [10] (pp. 64-88). 
Figure 1. Landings by demersal gear, Malacca Straits, 1975-1979 Source: [10].
Source: Directorate General of Fisheries, Fisheries Statistics of Indonesia, various years. Note: Numbers of fishers and boats are totals for the North Coast of Java. Demersal gear included in this table are Danish seine, Beach seine, shrimp gill nets, bottom-set gill nets, trammel nets, bottom-set long lines, hook and lines, guilding barriers, portable traps, and other traps. See [10] (pp. 64-88).

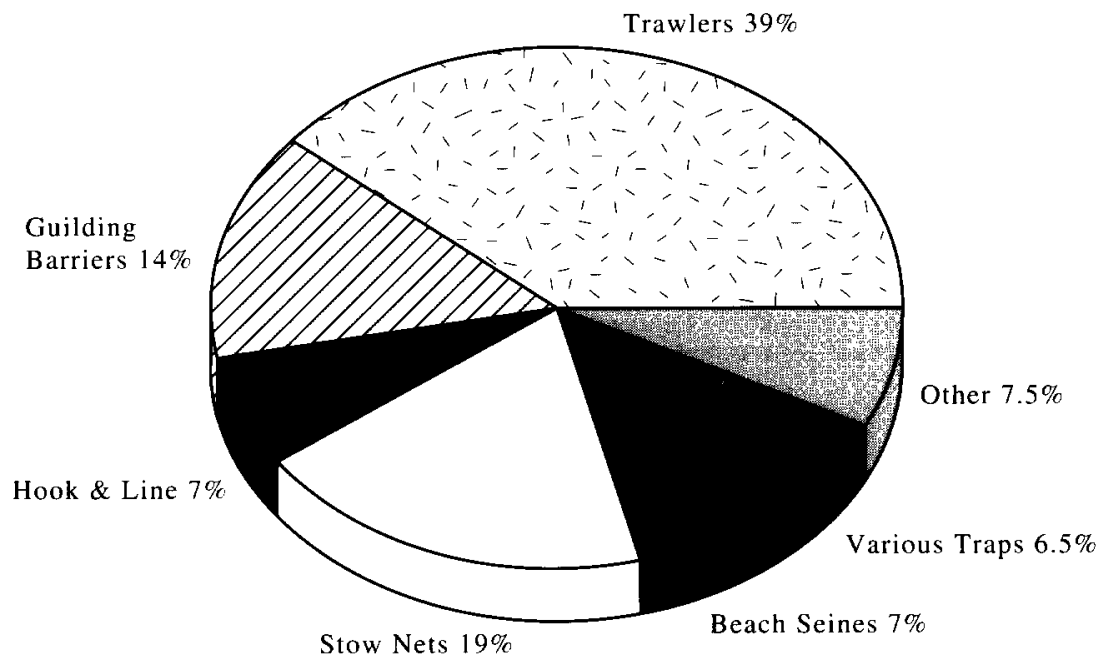

period 1975-1979 (Figure 1). During the same period, trawlers accounted for $40 \%$ of total demersal catch from the north coast of Java even though they accounted for only $2 \%$ of all demersal gear in that area (Table 3, Figure 2).

Prior to 1980, trawlers and small-scale fishers in Indonesia often found themselves in direct competition over access to the same fishing grounds and species [9]. In this competition, small-scale fishers were at a distinct disadvantage. The larger trawlers, often operating at night without lights, occasionally rammed smaller boats and damaged or destroyed gill nets or other small-scale gear. Similar problems have been reported in Malaysia [18], Thailand [5], and the Philippines [3]. Faced with a declining resource base and being pushed from their traditional fishing grounds, some small-scale fishers responded with violence. In Malaysia, between 1970 and 1973, over 60 boats were sunk and 23 fishers were killed [18].

Competition over a declining resource base also led to widespread violence in Indonesia. The press in Indonesia was (and is) more tightly controlled than elsewhere in Southeast Asia and did not report on this

\begin{tabular}{llll}
\hline \multicolumn{5}{l}{ Table 3. Small-scale demersal gear, North Coast of Java, 1975-1993 } \\
\hline Year & Number & Total landings (mt) & Catch rates (mt) \\
1975 & 45473 & 39308 & 0.86 \\
1976 & 26874 & 69425 & 2.58 \\
1977 & 32281 & 56810 & 1.76 \\
1978 & 22776 & 60114 & 2.64 \\
1979 & 34434 & 60247 & 1.75 \\
1980 & 34588 & 56845 & 1.64 \\
1981 & 35463 & 73307 & 2.07 \\
1982 & 37950 & 92170 & 2.43 \\
1983 & 36608 & 81501 & 2.27 \\
1984 & 37390 & 74316 & 1.99 \\
1985 & 33498 & 79868 & 2.38 \\
1986 & 33762 & 82249 & 2.44 \\
1987 & 36032 & 57379 & 1.59 \\
1988 & 37758 & 88768 & 2.35 \\
1989 & 38467 & 90993 & 2.37 \\
1990 & 39009 & 86713 & 2.22 \\
1991 & 39051 & 87514 & 2.24 \\
1992 & 43966 & 105092 & 2.39 \\
1993 & 44475 & 118686 & 2.66 \\
$\%$ change 1980-93 & 28.6 & 108.8 & 62.2 \\
\hline
\end{tabular}


Figure 2. Landings by demersal gear, North Coast of Java, 1975-1979. Source: [10].

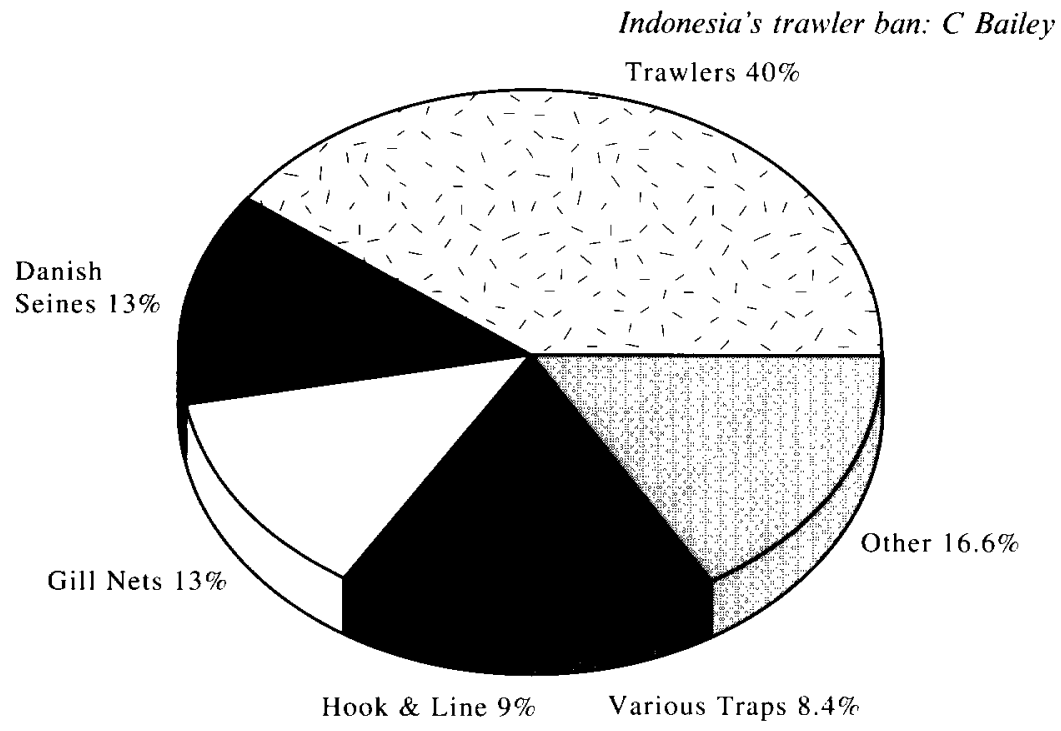

conflict. No official reports were made of casualties or damage to boats. Unofficial reports, however, suggest that open conflict occurred along the Malacca Straits and both the north and south coasts of Java [19]. A favorite weapon of small-scale fishers was the Molotov cocktail, which proved quite effective against wooden-hulled trawlers. From interviews conducted by the author during 1981-1982, it is clear that violence was widespread and serious. Beyond the burning of boats, there were people killed both on shore and at sea.

The government responded to this conflict with a series of regulatory measures designed to restrict trawlers from operating in coastal waters [10]. Efforts to enforce zone restrictions were hampered by the difficulty of enforcing such restrictions along thousands of kilometers of coastline without adequate personnel or equipment and in the absence of clearly defined enforcement responsibilities between government agencies [20]. The Director General of Fisheries at that time reported that over 1000 violations were recorded against trawlers but that enforcement efforts had had little effect [9].

The inability to control trawler operations and the mounting evidence that trawlers were depleting demersal resources in important fishing grounds were important factors contributing to the government's final decision to ban all trawling. Marine biologists working for government research institutes began expressing concerns about the impact of trawlers on demersal resources in the early 1970s [14]. These concerns were echoed by the Himpunan Nelavan Sa-Indonesia (Indonesian Fishers' Association), a quasi-governmental organization representing the interests of fishers within Indonesia's ruling party. However, in the final analysis it was the willingness of small-scale fishers to resort to violence that prompted decisive action on the part of the Indonesian government.

The government's sensitivity to this violence can be explained by recent political history. Bombings and killings along the Malacca Straits and coastal Java occurred roughly 10 years after a brief but extremely bloody period during 1965-1966 when upwards of 500000 people were killed in the aftermath of an attempted coup led by the Communist Party of Indonesia. This event had a profound influence on Indonesia's 
contemporary political culture, which places a heavy emphasis on stability. Uncontrolled violence threatened the stability which the New Order regime of President Soeharto claimed as a key achievement of his administration. Moreover, because many trawler owners were of Chinese descent, the government was concerned that expanding violence would take on a racial tone which would make it harder to control. Similar concerns were expressed across the Malacca Straits in Malaysia [4].

\section{The trawler ban}

Frustrated by the inability to regulate trawler operations and concerned by widespread unrest, the Indonesian government responded by imposing a total ban on all trawling. Unlike previous attempts at limiting operational zones, the total ban on trawlers proved comparatively easy to enforce. Bagan Siapi-api type trawlers are sufficiently large to require the facilities (wharf, ice plants and cold store facilities) of a substantial fishing port. Virtually all trawlers affected by the 1980 ban were based out of major fishing ports which could be easily controlled. Compared to previous efforts at zonation, a total ban was relatively simple to enforce from shore. More importantly, the fact that the directive came from the President himself gave added encouragement to enforcement efforts. The President's personal prestige at that time was relatively high and, although he had resigned from the military, he still had strong ties to this important institutional base. In short, the Presidential Decree was taken and acted upon as an order.

Seventeen years later, the trawler ban still holds, though there has been a little slippage along the way in some peripheral areas [20]. Along the Malacca Straits and the north coast of Java, however, the trawler ban continues to be effective. Nor is there any immediate prospect of a policy change. When asked whether there were plans to reintroduce trawlers, senior Indonesian policy makers and researchers alike invariably have replied in the negative. The issue was described as being "too sensitive" as it would create anew tensions in the affected coastal fishing communities. This sensitivity is due to concern that the reintroduction of trawlers would set off a new wave of violence. The experience of a government research vessel is indicative of the willingness of small-scale fishers to take direct action in defense of what they see as their interests. Several years after the trawler ban was first imposed, a government research vessel began a survey of demersal resources in waters off Java. The vessel was equipped with trawl gear for sampling demersal resources and was threatened with attack by local fishers. Local authorities were unable to guarantee the vessel's safety and the researchers had to abandon their survey. Local fishers were concerned that the purpose behind the survey cruise was to reestablish a trawler-based fishery and they responded with threats of violence [21]. Sensitivity to such threats as well as budgetary constraints have limited scientists' ability to measure the biological impact of the trawler ban [22].

\section{Impacts of the trawler ban}

For reasons noted above, there has been limited research on the effect of the trawler ban on demersal resources. A study off the north coast of 
Java, however, indicates that demersal stocks have increased dramatically since 1980 [22]. The catch rate per hour of a research vessel conducting a survey in 1986 was almost twice that obtained in 1979. indicating "recovery in the abundance of the demersal resources off the north coast of Java (p. 5)" [22]. This finding is supported by the increase in numbers of small-scale demersal gear in this coastal area and a modest improvement in their catch rates (Table 3 ). Unfortunately no comparable data are available on the Malacca Straits or in other areas where trawling had had significant impact on the resource base. However, indirect evidence indicates that elimination of trawlers from the Malacca Straits had a positive effect on demersal resources. Beginning in 1981, the number of small-scale demersal gear in the area increased dramatically, doubling in number from 1980 to 1990 (Table 2). Moreover, catch rates during this period were higher than before the trawler ban.

The elimination of trawlers did result in a short-term decline in total landings from the Malacca Straits; it was not until 1984 that landings reached the level of 1980. During the period 1980-1993, landings by small-scale demersal gear increased by $124 \%$ in this area, more than offsetting the loss due to elimination of trawlers (Figure 3). Overall landings from the north coast of Java recovered more quickly (equaling 1980 levels in 1982) due to the greater importance of pelagic fisheries in this area compared to the Malacca Straits. Here too, landings by smallscale demersal gear more than doubled between 1980 and 1993 (Figure 3), indicating that the elimination of trawlers opened up new opportunities for small-scale fishers. These data indicate that small-scale gear were able to replace trawlers in relatively shallow-water demersal fisheries. Small-scale fishers may not be able to operate as far off shore as trawlers were able to operate, but in reality trawlers in Indonesia typically did not operate offshore.

From the perspective of Indonesian policy makers, the most serious negative consequence of the trawler ban was an immediate decline in the volume of shrimp exports. Shrimp represent by far the most important source of foreign exchange earnings in Indonesia's fisheries sector. Prior to the 1980 ban, trawlers accounted for probably $70 \%$ of total shrimp exports worth $\$ 199$ million in 1979 (Table 4). This source of foreign exchange suddenly dried up. Shrimp export volume did not recover 1979 levels until 1986 and it was 1985 before shrimp export values equaled those of 1979 .

With elimination of trawlers as a source of supply, shrimp exporters increased their efforts to collect shrimp from scattered rural fishing communities. Prior to 1980 , many shrimp exporters had less incentive to

Figure 3. Landings (000s $\mathrm{mt})$ by small-scale demersal gear, 19751993.

Source: Directorate General of Fisheries, various years.

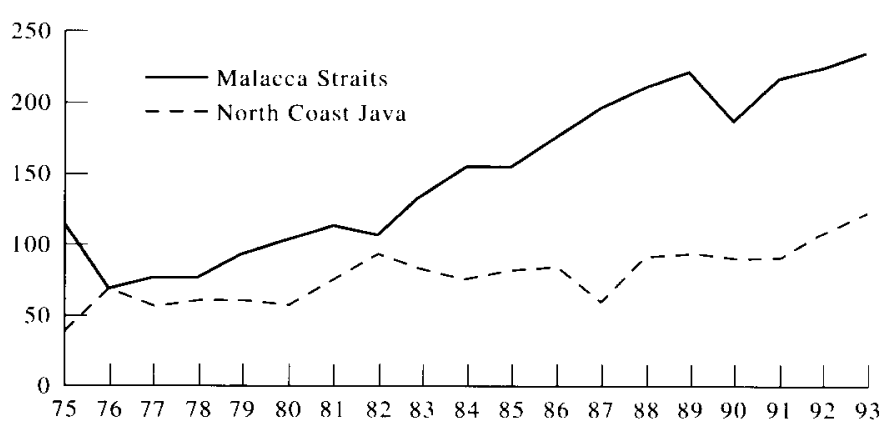


Sources: Directorate General of Fisheries, 1990 ; Central Bureau of Statistics, 1991.

\begin{tabular}{lcc}
\hline Table 4. Quantity (mi) and value (US\$) of trozen shrimp exports, Indonesia, 1979-1990 & \\
\hline Year & Quantity & Value \\
1979 & 33801 & 199.2 \\
1980 & 30548 & 178.4 \\
1981 & 23727 & 157.2 \\
1982 & 24665 & 178.1 \\
1983 & 24509 & 187.8 \\
1984 & 26357 & 192.1 \\
1985 & 28780 & 199.5 \\
1986 & 33992 & 280.7 \\
1987 & 40941 & 343.5 \\
1988 & 52294 & 489.1 \\
1989 & 71704 & 547.7 \\
1990 & n.a. & 671.6 \\
\hline
\end{tabular}

seek sources of supply among small coastal villages; it was far easier simply to take delivery of large volumes of shrimp brought to the exporter's dock by a trawler. After 1980, however, shrimp packers/ exporters quickly established marketing channels into rural areas. These efforts by the private sector were supported by government programs to strengthen the productive capacity of small-scale fishers through credit programs to motorize small-scale fishing boats and to purchase gear specifically designed to exploit demersal resources, including shrimp (e.g., trammel nets and shrimp gill nets).

The combination of government and private sector encouragement of small-scale fisheries certainly contributed to expanded participation in production for an export market. The combination of government loan programs and the high prices paid for shrimp served as powerful incentives to established fishers and new entrants alike. This said, the most significant factor in expanded shrimp exports during the late 1980s was increased production of pond raised shrimp. By 1989, pond produced shrimp accounted for $60 \%$ of total penaeid shrimp production in Indonesia, having surpassed marine landings two years earlier [23].

The trawler ban had a strong impact on employment on both the Malacca Straits and the north coast of Java (Figure 4). In both areas, numbers of fishers began increasing soon after the trawler ban was announced, reflecting rapid mobility of labor into the fishery. Between 1980 and 1993, the number of fishers operating along the Malacca Straits and the north coast of Java increased by $87 \%$ and $57 \%$, respectively. While the percentage increase was lower on Java, the base was larger. Total employment gain during this period along the north coast of Java was over 150000 compared to just under 100000 along the Malacca Straits. As impressive as are these numbers, they are lower than those for Indonesia as a whole, where the number of fishers nearly doubled between 1980 and 1993 [24].

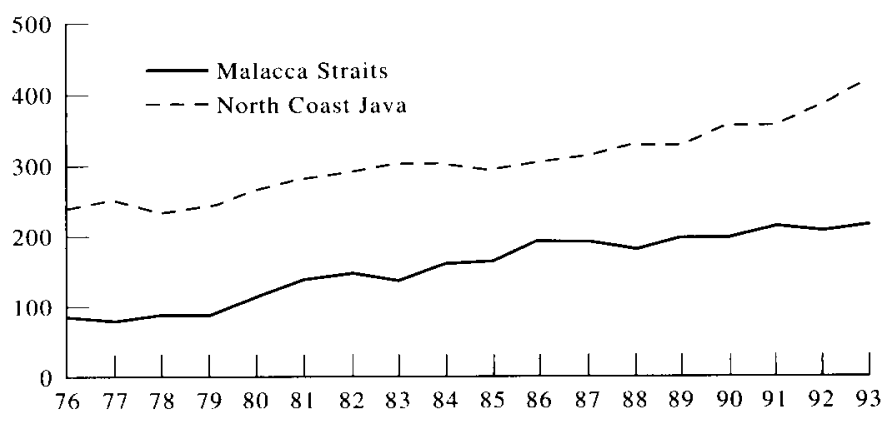


Growth in numbers of fishers in Indonesia as a whole makes it necessary to ask whether similar increases along the Malacca Straits and off the north coast of Java can be attributed to the trawler ban. Available evidence indicates that the trawler ban did have a direct impact on increasing employment among fishers in these two areas. Compared to the rest of Indonesia, by 1980 demersal resources of the Malacca Straits and the north coast of Java were heavily exploited and in some areas overexploited [10]. Under these conditions, the dramatic increases in landings by small-scale demersal gear could not have occurred without the removal of trawlers. Demersal landings by smallscale gear more than doubled in both areas. In the Malacca Straits, catch rates for small-scale demersal gear improved despite a near doubling in the number of gear between 1980 and 1993 (Table 2). During this period, small-scale demersal gear increased as a proportion of total gear operating (47-54\%) and accounted for an expanded share of total landings $(36-53 \%)[11,24]$. These figures strongly suggest that the elimination of competition from trawlers created opportunity for small-scale fishers to expand operations in the Malacca Straits. Using such indirect measures as presented here, it is not possible to state precisely what portion of increased employment in the fishery is attributable to the trawler ban, but for the Malacca Straits a conservative estimate is that at least half of the total increase (i.e., approximately 50000 jobs) could be traced to this policy.

A similar set of arguments can be made for the north coast of Java. The number of small-scale demersal gear increased by nearly $30 \%$ and catch rates improved over 60\% between 1980 and 1993 (Table 3). Small-scale demersal gear as a proportion of total gear increased slightly from $45 \%$ to $49 \%$ and their share of total harvests also increased from $17 \%$ to $24 \%[11,24]$. Pelagic fisheries are more important off the north coast of Java than they are in the Malacca Straits, and much of the employment growth in this area has been associated with pelagic rather than demersal fisheries. Nonetheless, perhaps one-quarter of the total increase in numbers of fishers (i.e., approximately 38000 jobs) might be traceable to the trawler ban.

These estimates of new employment opportunities created by the trawler ban are necessarily rough, but reflect reasonable approximations. The creation of perhaps 88000 new jobs is important, but this is a drop in the bucket in a marine sector which employed nearly 2 million fishers in 1993 [24].

\section{Lessons learned and not learned}

Indonesia's trawler ban represents one nation's dramatic response to a problem shared in common by most other nations in Southeast Asia. Through this action, the government effectively eliminated the most powerful fishing technology available for utilizing demersal resources. The effect has been to reallocate resource access to small-scale fishers as a class. In so doing, the government has recognized traditional resource use rights of small-scale fishers to be politically important. The elimination of trawlers has created new employment opportunities which were quickly filled. The rapid rush into the fishery is not surprising. As an open access resource, marine fisheries play an important role as a safety valve for surplus labor from other sectors of the Indonesian economy [10]. Particularly on Java, where population 
densities are extreme and landlessness among agriculturalists is common, the sea often offers a chance for a new start [25]. Similar conditions exist elsewhere in Indonesia as well, though not in such extreme a form. When trawlers were eliminated in 1980 , new entrants to the fisheries were attracted and established fishers increased their investments in productive capacity.

Taken alone, these can be seen as positive developments. However, the expansion of fishing effort by small-scale fishers may have the same effect on the resource base as did the trawlers. In his review of demersal stocks of the Java Sea after the trawler ban, Dwiponggo noted that total fishing effort applied to demersal stocks in 1984 was $34 \%$ below that of 1979 [22]. Since 1984, however, landings by smallscale demersal gear operating off the north coast of Java have grown by $60 \%$ (Table 3 ). Demersal stocks in this area are under heavy pressure, as is reflected by catch rates that are far lower than those in the Malacca Straits (Table 2). In short, the trawler ban has not eliminated the need to manage demersal resources. Because the resource is an open access system, no controls exist to limit the flow of new entrants into the fishery. In practical terms, there was little the government could do to forestall the increase in numbers of fishers and the growth in numbers of small-scale demersal gear. Problems of rural poverty are such that labor is highly mobile in response to new opportunities. The fate of Indonesia's fisheries resources are linked to problems of agricultural and industrial development, and specifically to the expansion of employment opportunities outside of the fishery. Until new opportunities are created elsewhere, labor will continue flowing into the fisheries sector. The end result is likely to be resource depletion and declining incomes - in short, conditions that existed prior to 1980.

What are the implications of the foregoing for other countries in Southeast Asia? One lesson appears to be that regulations which restrict trawlers from certain zones are far more difficult to impose than a complete ban, which can be enforced from shore at a limited number of fishing ports. Imposition of a gear ban is possible, but it requires substantial political will. No other country has shown such resolve or ability to reallocate access to an important resource to small-scale fishers. A second important lesson is that demersal stocks in the tropics appear to be capable of rebuilding after being overexploited. A third lesson is that elimination of trawlers does not necessarily mean a longterm decline in either landings or exports. Small-scale fishers using relatively simple gear appear able to utilize demersal resources as fully as trawlers. This capacity is, of course, a two-edged sword as eliminating trawlers is not going to solve problems of resource management. The need for rural and national development to attract labor and capital away from the fishery remains.

\section{References}

1. Pauly, D., Theory and Management of Tropical Multispecies; Stocks; a Review, with Emphasis on the Southeast Asian Demersal Fisheries. International Center for Living Aquatic Resources Management, Manila, 1979.
2. Martosubroto, P. and Naamin, N., Relationship between tidal forests (mangroves) and commercial shrimp production in Indonesia. Marine Research in Indonesia, 1977, 18, pp. 81-86

3. Bailey, C.. The blue revolution: the impact of technological innovation on third-world fisheries. The Rural Sociologist, 1985, 5(4), 259-266.

4. Goh Cheng Teik, The fishing conflict in Penang and Perak: personal memoir. Kajian Ekonomi Malaysia, 1976, XIII (1/2), 17-25. 
Panayotou, T., Economic conditions and prospects of small-scale fishermen in Thailand. Marine Policy. $1980,4(2), 142-46$

6. Smith, I. R., Research Framework for Traditional Fisheries. International Center for Living Aquatic Resources Management, Manila, 1979.

7. Bailey, C., Government protection of traditional resource use rights-the case of Indonesian fisheries. In Community Management; Asian Experience and Perspectives, ed. D. C. Korten, pp. 292-308. Kumarian Press, West Hartford, CT, 1986

8. Chong, K.-C., Dwiponggo, A., llyas, S. and Martosubroto, P., Some experiences and highlights of the Indonesian trawl ban: bioeconomics and socioeconomics. Proceedings of the Symposium on the Exploitation and Management of Marine Fishery Resources in Southeast Asia. Regional Office for Asia and the Pacific, Food and Agriculture Organization of the United Nations, Bangkok, 1987

9. Sardjono, I., Trawlers banned in Indonesia. ICLARM Newsletter, 1980, 3(4), 3 .

10. Bailey, C., Dwiponggo, A. and Marahudin, F., Indonesian Marine Capture Fisheries. International Center for Living Aquatic Resources Management, Manila, 1987.

11. Directorate General of Fisheries, Annual Fisheries Statistics 1980. Ministry of Agriculture, Jakarta, 1982.

12. Dudley, R. G. and Harris, K. C. The fisheries statistics system of Java, Indonesia: operational realities in a developing country. Aquacuiture and Fisheries Management, 1987, 18, pp. 365-374.
13. Naamin, N., Consequences of excessive fishing effort on fishery resources in Indonesia. In Proceedings of the Symposium on the Exploitation and Management of Marine Fishery Resources in Southeast Asia. Regional Office for Asia and the Pacific, Food and Agriculture Organization of the United Nations, Bangkok, 1987.

14. Unar, M., Review of the Indonesian Shrimp Fishery and its Present Development. Research Reports on Marine Fisheries, No. 1, Marine Fisheries Research Institute, Jakarta, 1972.

15. Baum, G. A, A cost-benefit calculation for Bagan-Siapi-Api trawlers operating from Semarang/Central Java. In Proceedings of the Symposium on Modernization of Small-Scale Fisheries, SMPR/78/S21. Marine Fisheries Research Institute, Ministry of Agriculture, Jakarta, 1978.

16. Ministry of Agriculture and Lands, Report on Costs and Earnings Survey of Malaysian Trawl Fisheries, Vol. 2. Fisheries Division, Ministry of Agriculture and Lands, Kuala Lumpur, 1970.

17. Naamin, N. and Farid, A., A review of the shrimp fisheries in Indonesia. In Report of the Workshop on the Biology and Resources of Penaeid Shrimps in the South China Sea Area-Part 1, SCS/GEN/80/26. South China Seas Fisheries Development and Coordinating Programme, Manila, 1980.

18. Gibbons, D. S., Public policy towards fisheries development in peninsular Malaysia; a critical review emphasizing Penang and Kedah. Kajian Ekonomi Malaysia, 1976, XIII (1/2), 89-121.
19. LaPorta, A. F., Pribumi fishermen and the trawlers. Unclassified letter to U.S. Embassies in Jakarta and Kuala Lumpur from U. S. Consulate in Medan, dated 5 December 1978.

20. Martosubroto, P., The status of management of the marine fishery resources in Indonesia. In Proceedings of the Symposium on the Exploitation and Management of Marine Fishery Resources in Southeast Asia. Regional Office for Asia and the Pacific, Food and Agriculture Organization of the United Nations, Bangkok, 1987.

21. Dwiponggo, A., Marine Fisheries Research Institute, personal communication, December 1984.

22. Dwiponggo, A., Recovery of overexploited demersal resources and growth of its fishery on the North Coast of Java. Indonesian Agricultural Research and Development Journal, 1988, 10(4), pp. 1-14.

23. Muluk, C. and Bailey, C., Social and environmental impacts of coastal aquaculture in Indonesia. In Aquacultural Development: Social Dimensions of an Emerging Industry, eds. C. Bailey, S. Jentoft and P. Sinclair, pp. 193-209. Westview Press, Boulder CO, 1996

24. Directorate General of Fisheries, Annual Fisheries Statistics 1993 Ministry of Agriculture, Jakarta 1995.

25. Collier, W. L., Soentoro, M. G., Basandaran, E., Santoso, K. and Stepanek, J. F., The acceleration of rural development on Java: from village studies to a national perspective. Occasional Paper No 06, February 1982. Agro-Economic Survey, Bogor, 1982. 